\title{
FABRICATION AND OPTIMIZATION OF SILICON SOLAR CELL CHARACTERISTICS BY USING POROUS SILICON LAYERS ON THE FRONT AND BACK SIDES
}

\author{
Hager A. Nawar ${ }^{1}$, Gamal M. Youssef ${ }^{2}$, Mahmoud M. El-Nhass ${ }^{3}$ and \\ Mohamed GH. El-Malky ${ }^{1}$ \\ ${ }^{1}$ Basic Science Department, Institute of Environmental Studies \& \\ Research, Ain Shams University \\ ${ }^{2}$ Physics Department, Faculty of science, Ain Shams University \\ ${ }^{3}$ Physics Department, Faculty of Education, Ain Shams University
}

\begin{abstract}
ABSTTRACT
Porous silicon layer (PSL) has emerged in potential solar cell applications because of its high surface area to volume ratio, convenient surface chemistry and large energy band gap $\approx 1.9 \mathrm{ev}$. PSL has been prepared from $\mathrm{n}^{+} \mathrm{p} / \mathrm{Si}$ junction using electrochemical etching (ECE) with three different current densities 25,50 and $75 \mathrm{~mA} / \mathrm{cm}^{2}$ on the front and back side of the junction. The influence of varying current density on morphological, optical, chemical and electrical properties of PS has been inspected. SEM micrographs showed that the surface porosity of $90 \%$ on the front side, in contrast the etched back surface seemed in harmonic shape with identical pore size and porosity of $98 \%$. The PL spectrum peak ranged from 640 to $670 \mathrm{~nm}$. PSL formed on both sides has the lowest reflectivity at current density of $50 \mathrm{~mA} / \mathrm{cm}^{2}$. The obtained
\end{abstract}


FTIR spectra of the samples with a relatively high PL intensity exhibit a developed broad transmission bands in the range of 600 to $4000 \mathrm{~cm}^{-1}$ Solar cell conversion efficiency of PSL formed on both sides is increased to $17 \%$ compared to other workers. Solar cell based on PSL formed on both sides provides stability and it is be recommended for industry manufacturing.

KEYWORDS: Porous silicon, Solar cell, Photoluminescence and Reflectance.

\section{INTRODUCTION}

Silicon ( $\mathrm{Si}$ ) is a suitable photovoltaic (PV) material due to its measured Energy band gap $\left(\mathrm{E}_{\mathrm{g}}\right)=1.12 \mathrm{eV}$ and availability, especially when compared to PV substrate such as titanium dioxide $\left(\mathrm{TiO}_{2}\right)$ of $\mathrm{E}_{\mathrm{g}}=3.20 \mathrm{eV}$ and cadmium selenide $(\mathrm{CdSe})$ of $\mathrm{E}_{\mathrm{g}}=1.94 \mathrm{eV}$ and cadmium sulphide $(\mathrm{CdS})$ of $\mathrm{E}_{\mathrm{g}}=2.42 \mathrm{eV}$, that all have higher bandgaps (Sun et al., 2014).

PSL was discovered coincidentally in 1956 by Uhlir while investigating the electrolytic etching of $\mathrm{Si}$ in hydrofluoric (HF) acid solutions. Since that, PSL has been harnessed for applications such as optoelectronics (Bisi et al., 2000), solar cells (Dzhafarov, 2013), batteries (Fang et al., 2013), and biomedical applications (Anglin et al., 2006). PSL is considered as a nano arranged form of silicon with a large surface volume ratio, that is fabricated through ECE technique (Sailor, 2014). the Photocurrent efficiency with n-type and p-type PSL (100) wafers of different crystal orientations had shown an increase in solar power when compared to planar silicon without PSL Salman 
et al (2012). However, the porosity of n-type PSL (100) was, much higher than for PSL p-type silicon (100). This research implied that Si solar cells that were modified with a PSL structure could considerably improve the maximum solar power. In contrast, the conversion efficiency of PSL formed on both sides increased in compared with one side etched sample Ramzy et al (2011). Surface texturing of $\mathrm{Si}$ also improves the antireflective properties, which reinforcing light trapping and conversion efficiency when compared to conventional Si solar cells, the importance of PSL in Si solar cells fabrication were summarized with (Dzhafarov, 2013).

In this research, we recently investigated the effect of PSL based on front, back and both sides of $\mathrm{n}^{+} \mathrm{p} / \mathrm{Si}$ junction on the electrical properties of $\mathrm{Si}$ solar cell and to investigate the morphological structures, optical properties and chemical composition of the prepared samples.

\section{EXPRIMENTAL DETAILS}

$\mathrm{CZ}$-Si substrate of $\mathrm{p}$ type (100) with resistivity of $5.0 \Omega$. $\mathrm{cm}$ thickness $\approx$ $450 \mu \mathrm{m}$ have been textured (Schneider et al., 2014) and undertaken a typical cleaning before the diffusion of phosphorus emitter $\left(\mathrm{POCl}_{3}\right)$, it has been used to longwinded textured substrates underneath optimum condition in order to generate an $\mathrm{n}^{+} \mathrm{p} / \mathrm{Si}$ junction on the front side of the material, the thickness of $\mathrm{n}$ layer was $\approx 1 \mu \mathrm{m}$. The substrate of type $\mathrm{n}^{+} \mathrm{p} / \mathrm{Si}$ were cut in to small pieces of size $1.5 \times 2.0 \mathrm{~cm}^{2}$ that was well-suited with the width of substrate holder by 
using a harden cutter tool. Thin homogenous PSL of different thicknesses were formed on the front $\mathrm{n}$ and back p-side surface of the material using ECE process. Before starting ECE, the samples were heated in Isopropyl Alcohol (IPA) at $75 \mathrm{C}^{\mathrm{a}}$ for $30 \mathrm{~min}$. Many studies reported that adding (IPA) increases the wettability of the silicon surface and then removes the observing hydrogen bubbles sticking on the surface (OU et al., 2011; Youssef et al., 2015b), after that the small pieces of samples were immersed in deionized water (DI) water for $5.0 \mathrm{~min}$ and dried under the stream of nitrogen gas.

The ECE process was performed to produce three groups of samples by using a 1:3 mixture of $40 \% \mathrm{HF}$ : $95 \%$ ethanol (volume ratio) as an electrolyte and variation of current density of 25,50 and $75 \mathrm{~mA} / \mathrm{cm}^{2}$ for group I, group II and $50 \mathrm{~mA} / \mathrm{cm}^{2}$ for group $\amalg$ under a fixed etching time of $25 \mathrm{~min}$. Group I consists of 3 samples of PSL $\left(\mathrm{Sn}_{1}, \mathrm{Sn}_{2}\right.$ and $\left.\mathrm{Sn}_{3}\right)$ formed on the front $\mathrm{n}$-side [PS/n $/ n^{+} \mathrm{p} / \mathrm{Si}$, group II consists of 3 samples of PSL $\left(\mathrm{Sp}_{1}, \mathrm{Sp}_{2}\right.$ and $\left.\mathrm{Sp}_{3}\right)$ formed on the back p-side $\left[\mathrm{PS} / \mathrm{pn}^{+} / \mathrm{Si}\right]$ and group $\amalg$ consists of 2 samples of PSL $\left(\mathrm{Sn}_{4}\right.$ and $\mathrm{Sp}_{4}$ ) formed on the both sides $\left[\mathrm{PS} / \mathrm{n}^{+} \mathrm{p} / \mathrm{Si} / \mathrm{PS}\right]$ and $\left[\mathrm{PS} / \mathrm{p} \mathrm{n}^{+} / \mathrm{Si} / \mathrm{PS}\right]$ respectively. the formation of PSL by ECE process was done without any illumination (Yerokhov et al., 2000; Youssef et al., 2015a).

Ethanol is usually added to make the removal of $\mathrm{H}_{2}$ bubbles simpler, these bubbles can easily affect the surface since the liquid surface tension is decreased. Moreover, the mixing of ethanol in electrolyte helps to improve the 
uniformity of the PSL (Dubey and. Gautam, 2009). To form a good ohmic contact, Al electrode was placed in back contact with samples and acts as anode. The platinum $(\mathrm{Pt})$ counter acts as cathode as shown in Fig. 1.

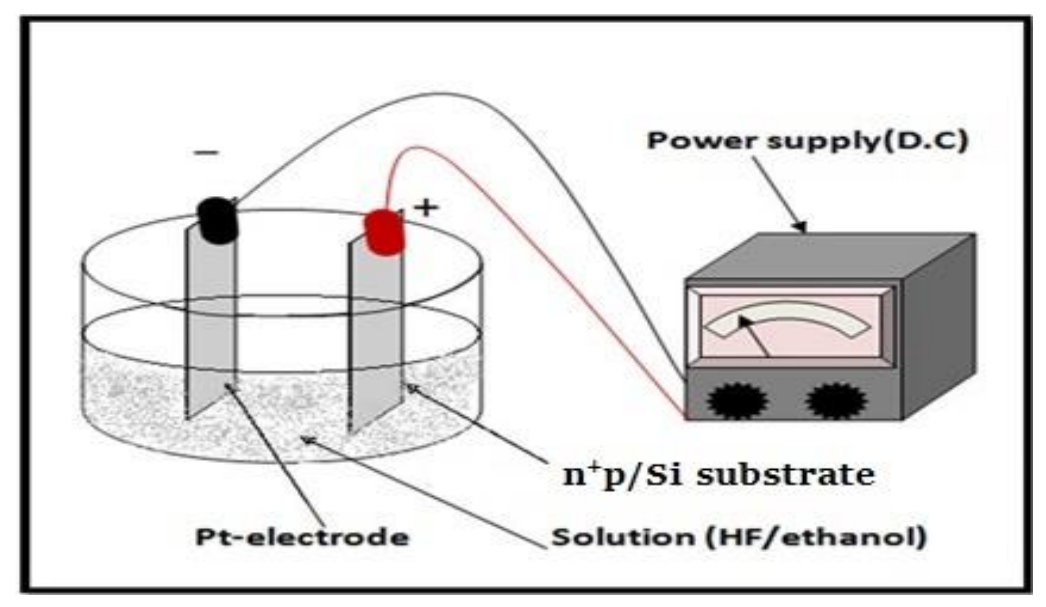

Figure 1: The electrochemical etching system (schematic diagram).

The anodization process was carried out with the distance between the sample to the Pt counter electrode fixed at $\approx 1.0 \mathrm{~cm}$. After the anodization, the PSL were rinsed first with acetone for $2.0 \mathrm{~min}$, then with $95 \%$ Ethanol for 2.0 min, and finally with deionized water. the samples were dried with a stream of nitrogen gas at low pressure to protect PSL surface formed from cracking.

To formulate solar cell: after PSL formed on the surface of both front $n$ and back p-side of samples. Aluminum (Al) evaporation was used for back surface contact and gold (Au) for front metallization. The evaporation process 
was carried out using high vacuum coating unit (Edward E306A England), the samples-coated electrodes were annealed at $450 \mathrm{c}^{\circ}$ in argon atmosphere. The construction of PSL solar cell be made up of metal mask of grid pattern with

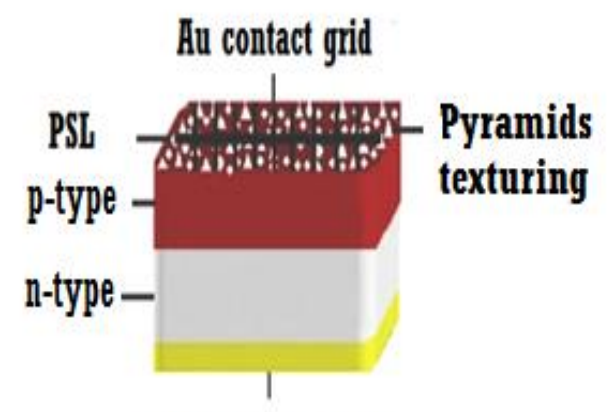

AL back contact

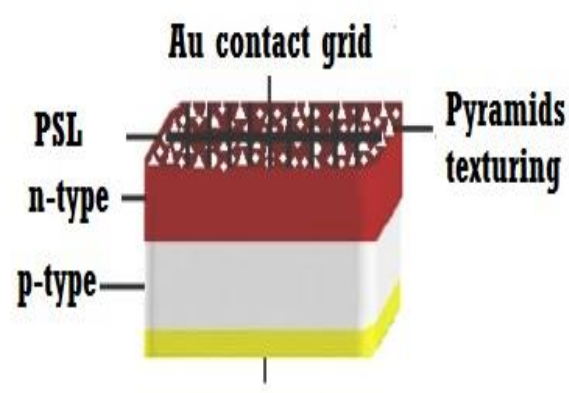

Ill back contact

finer width of $0.05 \mathrm{~cm}$ and finger spacing of $0.1 \mathrm{~cm}$.

(a)

(b)

Figure 2. Solar cells based on PSL and pyramids texturing samples for (a): front nside and (b): back p-side.

Morphological properties of the PSL formed on the front n-side and back p-side are characterized by using high resolution scanning electron microscopy (SEM) inspect S. The photoluminescence (PL) measurement were carried out using (RF-5301 Spectrofluorophotometer, Shimadzu) by using 150W Xenon excitation lamp with wavelengths are in range of 200-999 $\mathrm{nm}$. spectrophotometer (UV VIS-NIR 3600 Spectrometer, Shimadzu) used to record surface reflectivity of PSL. Fourier transform infrared (FTIR) spectrometer 
used for the measurement of chemical composition of PSL samples is a (Nicolet 6900 FTIR, thermoscientific, class1). Finally, electrical (J-V) characteristics of samples have been measured after fabrication of the solar cell device by using keithely 2400 source meter.

\section{EXPERIMENTAL RESULTS AND DISSCUSSION}

\section{Surface morphology:}

\subsection{Group I samples:}

Figure 3-a shows SEM of the front n-surface without PSL formation, the shape of the front n-surface is presented in pyramidal form. By starting ECE process and applying current density of $25 \mathrm{~mA} / \mathrm{cm}^{2}$ Fig. 3-b, A discrete pores with small size are shaped, the whole surface is blocked with spiderwebbed (sample $\mathrm{Sn}_{1}$ ). When current density is increased to $50 \mathrm{~mA} / \mathrm{cm}^{2}$ (sample $\mathrm{Sn}_{2}$ ) Fig. 3-c, the obtained pores become more homogeneous and disciplined in size and the whole surface is entangled. By implementation of current density of $75 \mathrm{~mA} / \mathrm{cm}^{2}$ (sample $\mathrm{Sn}_{3}$ ), an important notice that the number of pores are decreased, and the surface is intermittent with dendritic wall pattern Fig. 3-d. the average pore diameter and thickness of samples are listed in Table 1. 

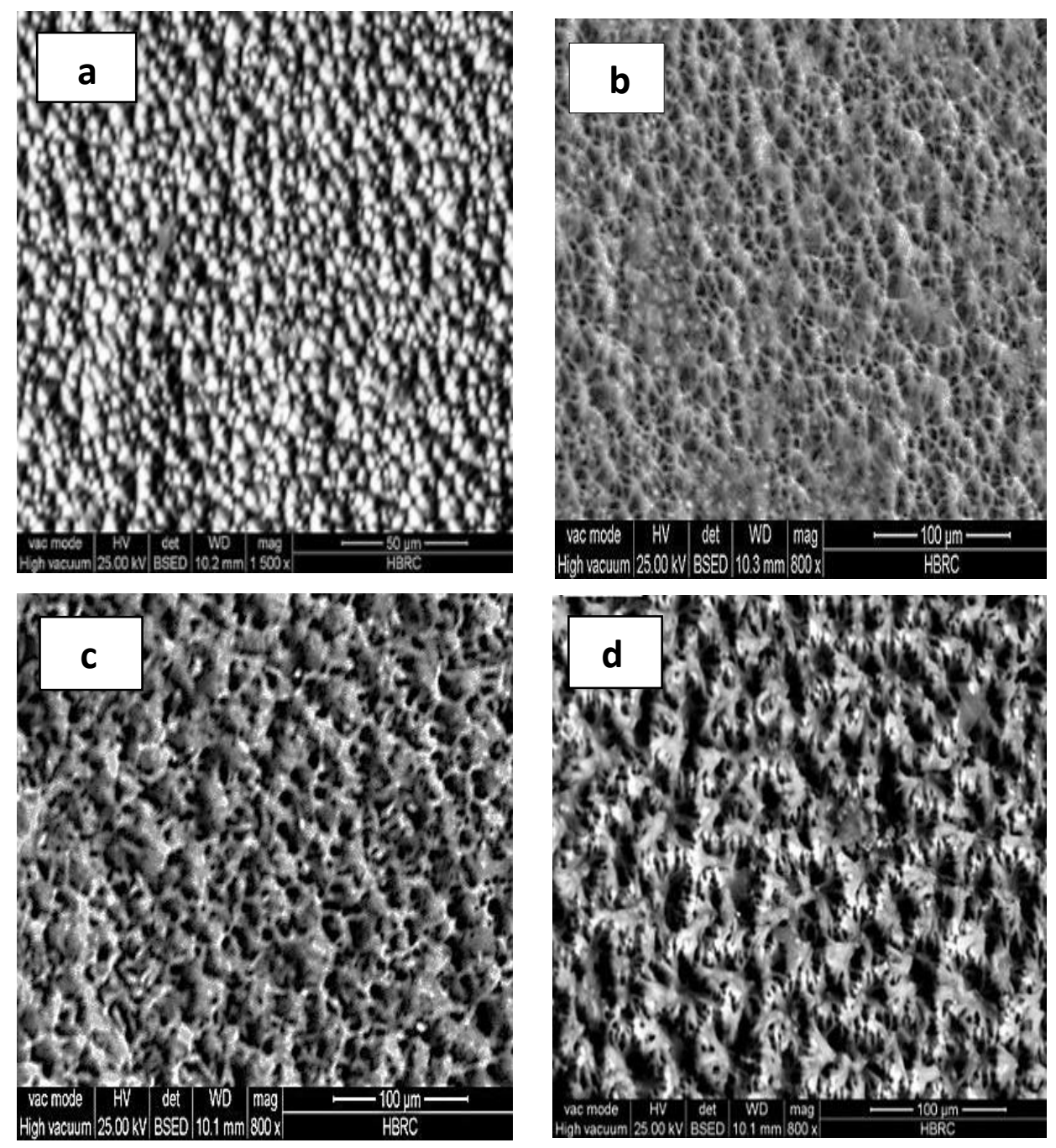

Figure 3. SEM of: (a) front $\mathrm{n}^{+} \mathrm{p} / \mathrm{Si}$ without PSL, (b), (c) and (d) for PSL samples $\mathrm{Sn}_{1}, \mathrm{Sn}_{2}$ and $\mathrm{Sn}_{3}$ prepared at $25,50 \& 75 \mathrm{~mA} / \mathrm{cm}^{2}$ for fixed time of $25 \mathrm{~min}$ and electrolyte concentration (1:3). 


\subsection{Group I samples:}

Figure 5-a represents SEM of the back p-surface without PSL, the shape is also organized in pyramidal form, but the size of pyramids is seemed to be smaller than that of the front n-surface (Fig.3-a). By applying current density of $25 \mathrm{~mA} / \mathrm{cm}^{2}$ (sample $\mathrm{Sp}_{1}$ ), many disconnected holes are presents Fig.4-b however, the pore is greater in number and the surface seems to be more etched in compare with that appears in sample $\mathrm{Sn}_{1}$. When current density is increased to $50 \mathrm{~mA} / \mathrm{cm}^{2}$ Fig. 4-c, the surface seems in Harmonic shape with identical pore size and encashments in addition that, the obtained pores are larger in size than in sample $\mathrm{Sp}_{1}$ and the pores appear totally couple with each other in compare with the pore formed on the front n-surface (sample $\mathrm{Sn}_{2}$ ) that has discrete pores with smooth walls, in addition to short branches pores. (salman et al., 2012, Youssef et al., 2015b). With operation of current density of $75 \mathrm{~mA} / \mathrm{cm}^{2}$ Fig. 4-d, the surface is distributed in branched wedges (sample $\mathrm{Sp}_{3}$ ), and the pore size is shrunken in compare with pore shaped on sample $\mathrm{Sn}_{3}$ (Kulathuraan et al., 2016). the average pore diameter and thickness of samples are listed in Table $\mathbf{1 .}$ 

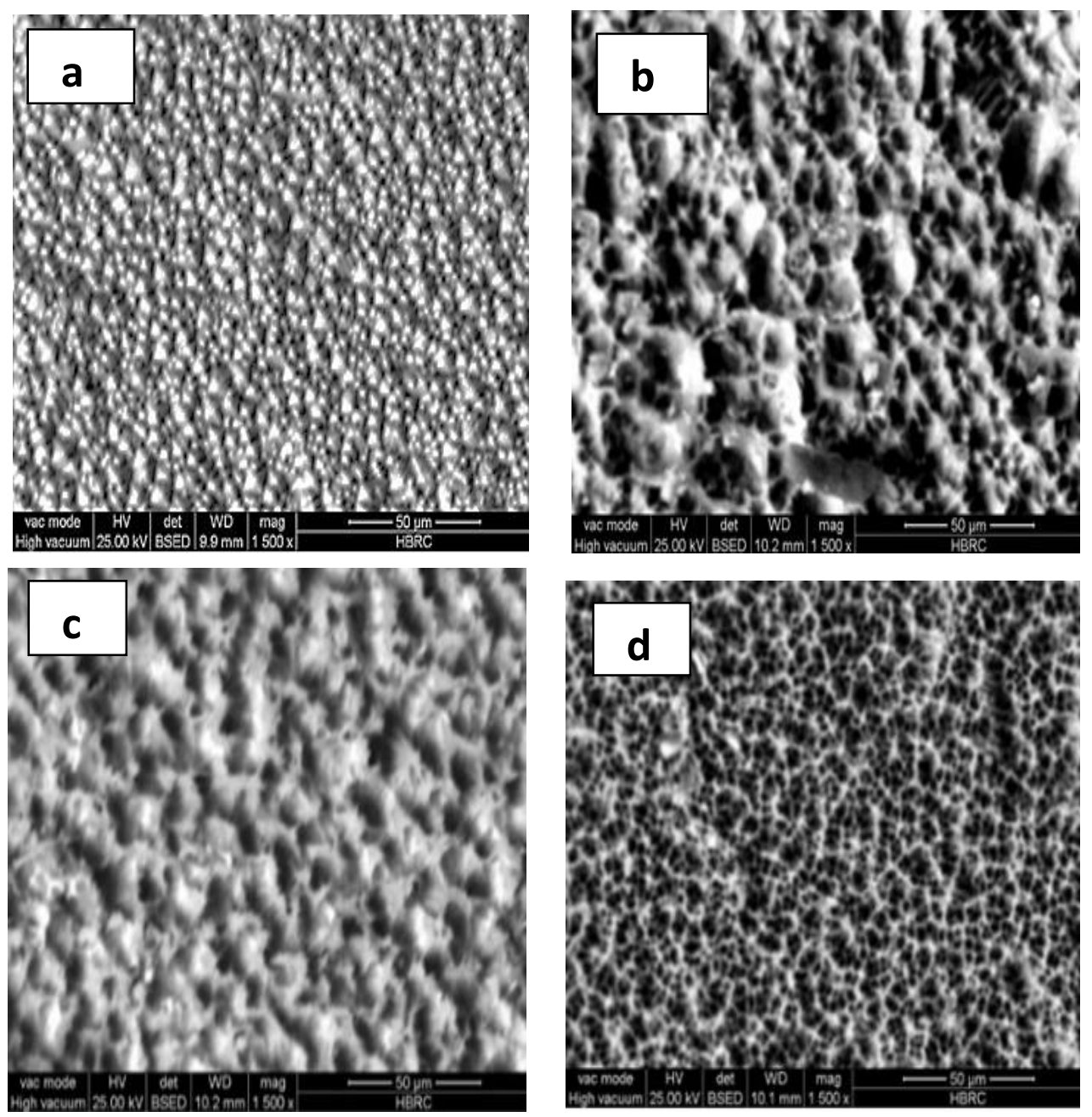

Figure 4. SEM for: (a): $\mathrm{n}^{+} \mathrm{p} / \mathrm{Si}$ without PSL, (b), (c) and (d) for PSL samples $\mathrm{Sp}_{1}, \mathrm{Sp}_{2}$ and $\mathrm{Sp}_{3}$ prepared at $25,50 \& 75 \mathrm{~mA} / \mathrm{cm}^{2}$ for fixed time of $25 \mathrm{~min}$ and electrolyte concentration (1:3). 
The term porosity can be defined as a function of geometrical parameters is given in Eq. 1 (Salcedo et al., 1999, Kulathuraan et al., 2016),

$$
\mathbf{P}=\left(\frac{\pi}{2} * 1.932\right)\left(\frac{1}{1+\frac{m}{d}}\right)^{2} \ldots \ldots \ldots \ldots \ldots \ldots . . . . .(1)
$$

Where $\mathrm{d}$ is the average pore size and $\mathrm{m}$ is the distance between pores. Using the above equation, the calculated porosity values are given in Table 1 .

Table 1. Average pore diameter, measured thickness \& Porosity for PSL prepared on the front $n-$ side (samples $\mathrm{Sn}_{1}, \mathrm{Sn}_{2}$ and $\left.\mathrm{Sn}_{3}\right)$ and the back p-side $\left(\mathrm{Sp}_{1}, \mathrm{Sp}_{2}\right.$ and $\left.\mathrm{Sp}_{3}\right)$.

\begin{tabular}{|l|l|l|l|l|l|l|l|}
\hline Sample & $\begin{array}{c}\text { Average pore } \\
\text { diameter } \\
(\mu \mathrm{m})\end{array}$ & $\begin{array}{c}\text { Measured } \\
\text { thickness } \\
(\mu \mathrm{m})\end{array}$ & $\begin{array}{c}\text { Porosity } \\
\%\end{array}$ & Sample & $\begin{array}{c}\text { Average pore } \\
\text { diameter } \\
(\boldsymbol{\mu m})\end{array}$ & $\begin{array}{c}\text { Measured } \\
\text { thickness } \\
(\boldsymbol{\mu m})\end{array}$ & $\begin{array}{c}\text { Porosity } \\
\%\end{array}$ \\
\hline $\mathbf{S n}_{1}$ & 4.0 & 45.2 & 73.6 & $\mathbf{S p}_{1}$ & 3.6 & 13.0 & 80 \\
\hline $\mathbf{S n}_{2}$ & 6.4 & 67.2 & 90.0 & $\mathbf{S p}_{2}$ & 6.1 & 33.5 & 98 \\
\hline $\mathbf{S n}_{3}$ & 5.6 & 50.0 & 79.0 & $\mathbf{S p}_{3}$ & 4.5 & 16.0 & 87 \\
\hline
\end{tabular}

So, we can conclude that the samples $\mathrm{Sn}_{2}$ and $\mathrm{Sp}_{2}$ at current density of $50 \mathrm{~mA} / \mathrm{cm}^{2}$ exhibit the most uniform homogeneous PSL surface and quantum wire structure of thin string pillar silicon walls, it may be expected to exhibit the quantum confinement effects (QCE) owing to the aggregates of nano crystallite silicon in the etched layer. (Dian et al., 2004). 


\section{2-Photoluminescence spectra (PL):}

\subsection{GroupI samples:}

Figure 5-a express PL spectra of PSL formed on the front n-side $\mathrm{Sn}_{1}, \mathrm{Sn}_{2}$ and $\mathrm{Sn} 3$ for different etching current densities with the excitation wavelength at $\lambda=325 \mathrm{~nm}$. The emitted band is detected around 685 and the calculated $\mathrm{Eg}_{\mathrm{g}}$ using the PL spectra giving in Eq. 2 is found in the range of $1.91 \mathrm{eV}$.

$$
\mathbf{E}_{\mathbf{g}}=\frac{1240}{\lambda} \ldots \ldots \ldots \ldots \ldots
$$

The increasing value in $E_{g}$ indicates that, blue shift maximum and the particles are confined to the lower dimension which directed to high efficiency according to the quantum confinement effects (Omar, 2009; Ramizy et al., 2011, Salman, 2012; Kulathuraan et al., 2016, Youssef, 2016). This is as result of increasing the total volume of the pores and relative to the number of released photons on the PSL surface (SEM studies), While the PL intensity emission band drop for sample $\mathrm{Sn}_{3}$. A possible reason might be formation of dendritic pore pattern, broadening of the pore walls and decrease numbers of pores on the PSL surface and thus decreases the porosity (SEM results) which prevents good light absorption. 

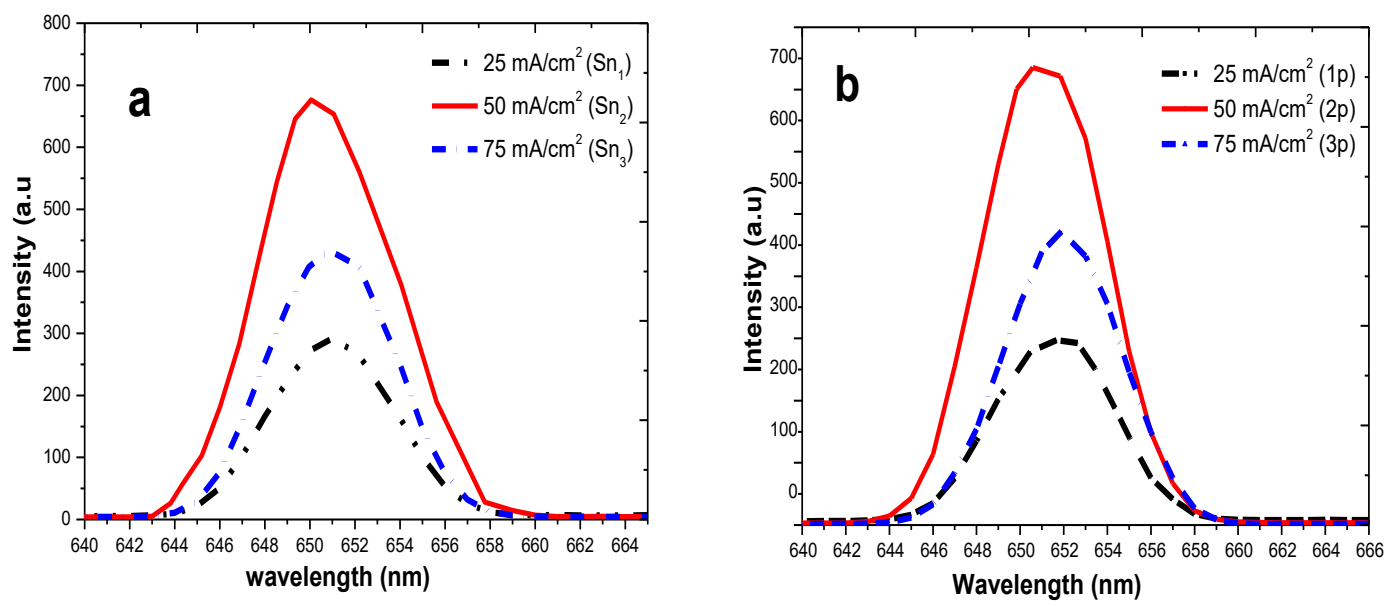

Figure 5. Photoluminescence of PSL samples prepared on (a): the front $n$-side $\left(\mathrm{Sn}_{1}, \mathrm{Sn}_{2}\right.$ and $\left.\mathrm{Sn}_{3}\right)$ and (b): back p-side $\left(\mathrm{Sp}_{1}, \mathrm{Sp}_{2}\right.$ and $\left.\mathrm{Sp}_{3}\right)$

\subsection{Group I samples:}

Figure 5-b describe the PL spectra of PSL formed on the back p-side $\mathrm{Sp}_{1}, \mathrm{Sp}_{2}$ and $\mathrm{Sp}_{3}$. The result is similar to that obtained in group I samples, The maximum peak intensity accomplish to 675 (a.u) for sample $\mathrm{SP}_{2}$ and the computed $E_{\mathrm{g}}$ using Eq. 2 is about 1.905 (ev) while, the intensity peak for sample $\mathrm{Sp}_{3}$ is decreased to 430 (a.u) as a result of the discount in average pore size and layer thickness, and thus decreasing its porosity this come to an agreement with other reporters (Rajabi et al., 2009; Kulathuraan et al., 2016). The recorded PL intensities (broadening and height) and hence obtained $\mathrm{Eg}_{\mathrm{s}}$ of PSL formed on front $\mathrm{n}$-side are higher than that formed on the back $\mathrm{p}$-side 
because of the effect of the growth of its average pore size and layer thickness see

\begin{tabular}{|c|c|c|c|c|}
\hline Sample & $\therefore(\mathbf{n m})$ & Intensity (a.u) & FWHM (nm) & $E_{g}$ (e.v) \\
\hline \multicolumn{5}{|c|}{ Group I } \\
\hline $\mathbf{S n}_{1}$ & 651.4 & 280 & 6.0 & 1.903 \\
\hline $\mathrm{Sn}_{2}$ & 649.8 & 685 & 8.0 & 1.910 \\
\hline $\mathrm{Sn}_{3}$ & 651.0 & 430 & 7.5 & 1.904 \\
\hline \multicolumn{5}{|c|}{ Group П } \\
\hline Sp1 & 651.7 & 240 & 6.0 & 1.902 \\
\hline $\mathrm{Sp}_{2}$ & 650.6 & 675 & 7.5 & 1.905 \\
\hline $\mathrm{Sp}_{3}$ & 651.9 & 420 & 7.0 & 1.903 \\
\hline
\end{tabular}

\section{Table 2.}

Table 2. intensity, FWHM and calculated Eg for: PSL samples prepared on front $\mathrm{n}-$ side $\left(\mathrm{Sn}_{1}, \mathrm{Sn}_{2}\right.$ and $\left.\mathrm{Sn}_{3}\right)$ and back $\mathrm{p}-$ side $\left(\mathrm{Sp}_{1}, \mathrm{Sp}_{2}\right.$ and $\left.\mathrm{Sp}_{3}\right)$.

\section{Reflectance measurements:}

\subsection{Group I samples:}

Figure 6-a illustrates the reflection spectra of PSL samples formed on front $\mathrm{n}$ side. The reflectance decreases from $12.8 \%$ to $9.6 \%$ and then increasing 
again to $10.5 \%$ for samples $\mathrm{Sp}_{1}, \mathrm{Sp}_{2}$ and $\mathrm{Sp}_{3}$ respectively compared with that without PSL $(\mathrm{R}=35 \%)$. The lowest effective light reflection is obtained from sample $\mathrm{Sn}_{2}$ that consisted of meso-pores compared with reflectivity's of the other samples.

The maximum reduction in light reflection ranged from 300 to $700 \mathrm{~nm}$, due to the increasing in the roughness expected to increase the light scattering in PSL, then reduce the reflectivity. Using PSL as antireflection coating (ARC) layer in the solar cells designs is a very important, it lead to the increase in light absorption in the visible region of the solar spectrum that is predictable to increase the efficiency of
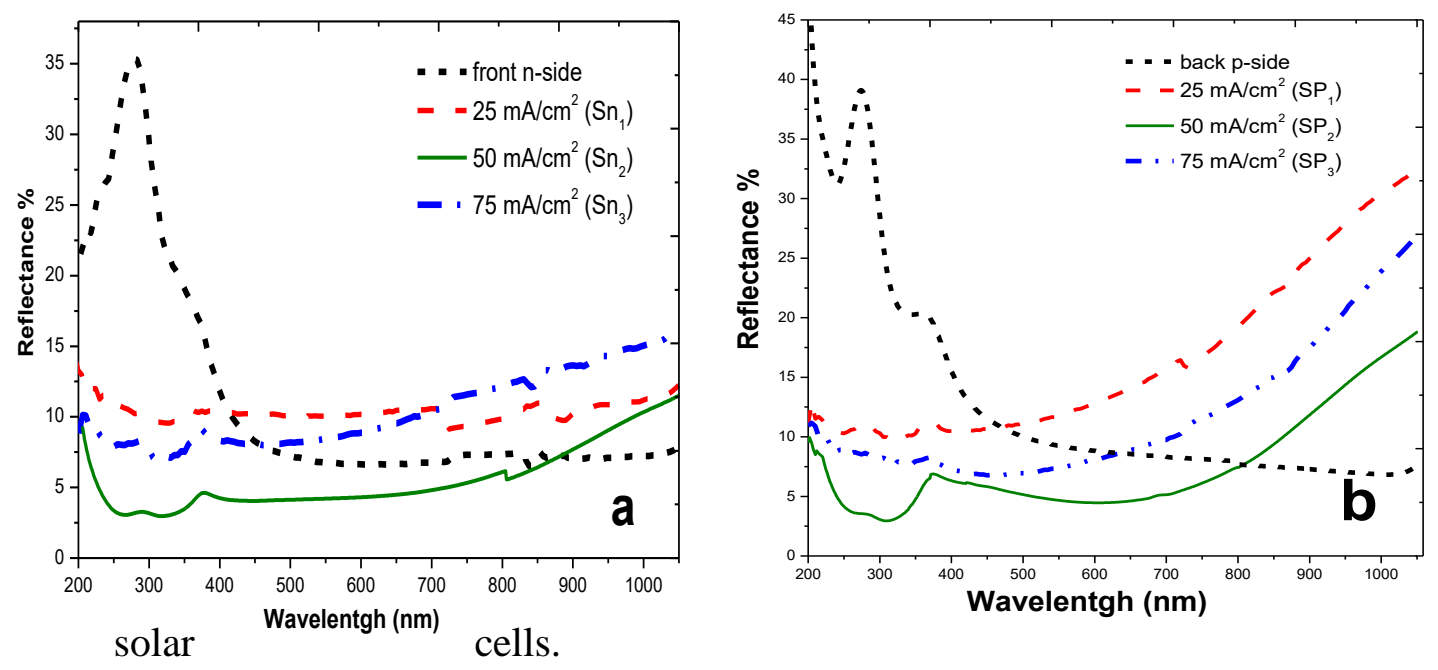
Figure 6. Reflectance of PSL samples prepared on (a): the front n-side $\left(\mathrm{Sn}_{1}, \mathrm{Sn}_{2}\right.$ and $\left.\mathrm{Sn}_{3}\right)$ and (b): back p-side $\left(\mathrm{Sp}_{1}, \mathrm{Sp}_{2}\right.$ and $\left.\mathrm{Sp}_{3}\right)$ corresponding to front $\mathrm{n}$ and back $\mathrm{p}$-side without PSL layer.

\subsection{Group II samples:}

The reflectance curve that obtained in PSL samples formed on back pside are presented in Fig. 6-b. The reflectance decreases from 12.5\% to $10 \%$ and then increasing again to $11.2 \%$ for PSL samples: $\mathrm{Sp}_{1}, \mathrm{Sp}_{2}, \mathrm{Sp}_{3}$ respectively compared with that of back p-side sample without PSL ( $\mathrm{R}=39 \%)$. this agrees with the previous results obtained from PL measurements. In general comparison the reflectivity curves measured for PSL samples formed on front $\mathrm{n}$-side PSL are higher than that measured for PSL samples formed on back p-side. this can be due to the increasing in pore size and layer thickness leads to increasing in light absorbing and decreasing its surface reflectivity. this agree with pervious author's (Ramizy et al., 2011; salman et al., 2012, Youssef et al., 2016).

As in similar, the sample $\mathrm{Sp}_{2}$ give the most lower surface reflectivity response comparing to other sample data recorded $\left(\mathrm{Sp}_{1}\right.$ and $\left.\mathrm{Sp}_{3}\right)$. these results lead to a conclusion that both samples $\mathrm{Sn}_{2}$ and $\mathrm{Sp}_{2}$ give the best optimum reflectivity data obtained and hence are most profitable to be used in manufacturing the solar cells and is predictable to increase light absorption in the visible region of the solar spectrum so that increasing the solar cells efficiency. 


\subsection{Optical Eg calculation:}

$E_{\mathrm{g}}$ values for PSL formed on front $\mathrm{n}$ and back $\mathrm{p}$-side are calculated from reflectivity curves by using Ku-Munk Equation (Kubelka, 1931; Kubelka, 1946; Tauc et al., 1966) and listed in Table 3,

$$
\mathbf{F}(\mathbf{R}) h v=\mathbf{A}\left(h v-\mathbf{E}_{\mathrm{g}}\right)^{\mathbf{n}}
$$

Where $F(R)$ is proportional to the absorption coefficient $(\alpha)$. And $\mathbf{F}(\mathbf{R})=$ $\frac{(1-R)^{2}}{2 R}$ (Otsuka, 2004) and $\mathrm{A}$ is the edge width parameter representing the film quality, $h v$ is the incident photon energy, $\mathbf{E}_{\mathbf{g}}$ is optical gap and $\mathrm{n}$ is constant determines the type of transition, $n=1 / 2$, for the direct allowed transition and 2 for indirect allowed transition.
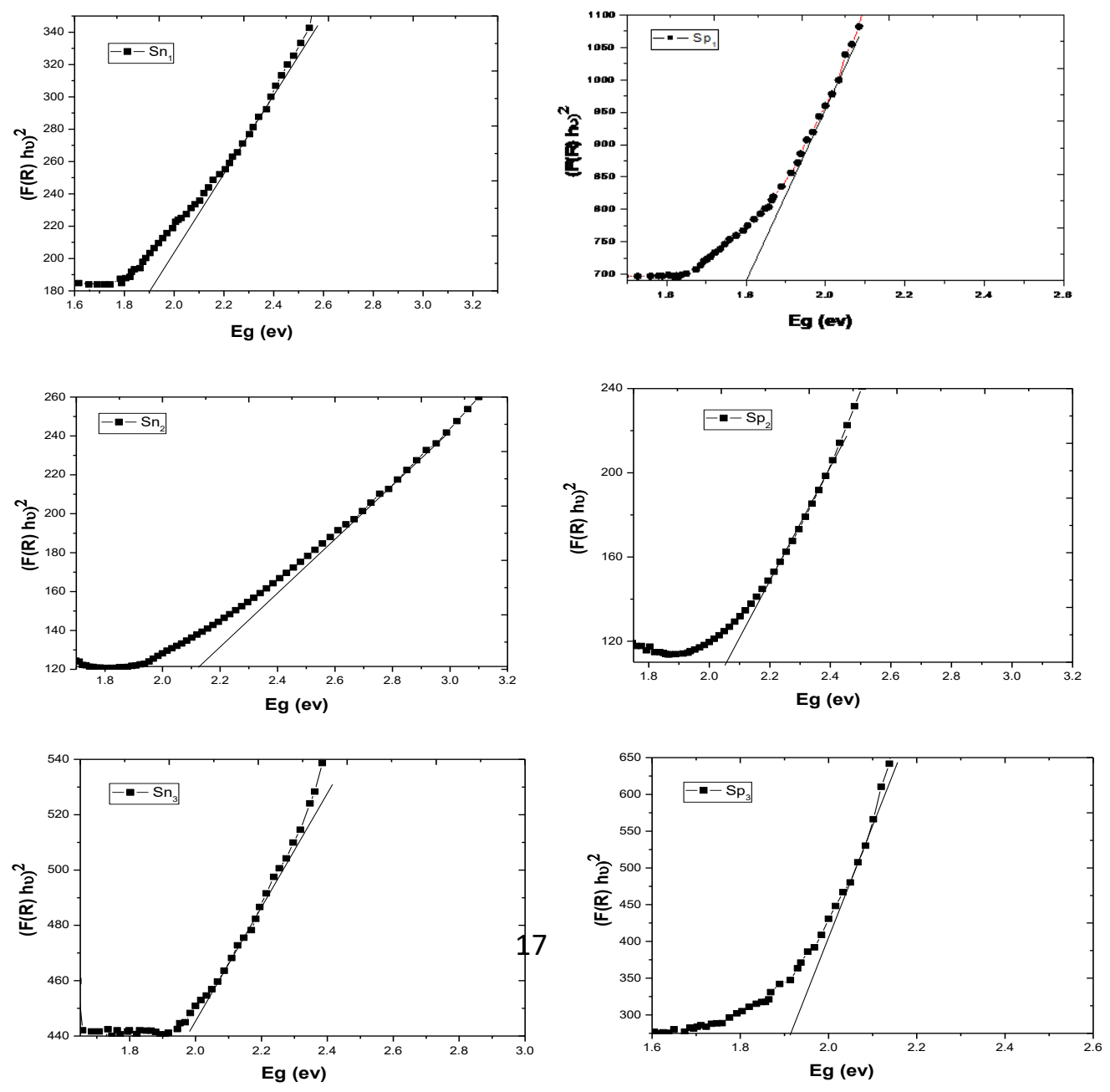
Figure 7. Different plots of $(F(R) h v)^{2}$ versus $h v$ for PSL samples prepared on (a): the front $n-$ side $\left(\mathrm{Sn}_{1}, \mathrm{Sn}_{2}\right.$ and $\left.\mathrm{Sn}_{3}\right)$ and (b): back p-side $\left(\mathrm{Sp}_{1}, \mathrm{Sp}_{2}\right.$ and $\left.\mathrm{Sp}_{3}\right)$.

Table 3. give comparison between the calculated band gap of the samples by extrapolation the absorption edge onto the energy axis using Eq. 3 and that extracted from PL data.

\begin{tabular}{|c|c|c|c|}
\hline \multirow[t]{2}{*}{ Sample } & \multirow{2}{*}{$\begin{array}{c}\text { Thickness } \\
(\mu \mathrm{m})\end{array}$} & \multicolumn{2}{|c|}{$E_{g}(e V)$} \\
\hline & & PL (a.u) & UV-Vis-NIR \\
\hline \multicolumn{4}{|c|}{ Group I } \\
\hline $\mathbf{S n}_{1}$ & 45.25 & 1.903 & 1.905 \\
\hline $\mathrm{Sn}_{2}$ & 67.2 & 1.910 & 2.140 \\
\hline $\mathbf{S n}_{3}$ & 50.0 & 1.904 & 1.98 \\
\hline \multicolumn{4}{|c|}{ Group II } \\
\hline Sp 1 & 13.0 & 1.902 & 1.805 \\
\hline $\mathrm{Sp}_{2}$ & 33.5 & 1.905 & 2.080 \\
\hline $\mathrm{Sp}_{3}$ & 16.0 & 1.903 & 1.920 \\
\hline
\end{tabular}


From Table 3 The values of $\mathrm{E}_{\mathrm{g}}$ obtained for samples $\mathrm{Sn}_{1}, \mathrm{Sn}_{2}$ and $\mathrm{Sn}_{3}$ are higher than $\mathrm{Sp}_{1}, \mathrm{Sp}_{2}$ and $\mathrm{Sp}_{3}$, this due the increasing in layer thickness and light absorbing of PSL samples formed on front side lead to widening $E_{g}$ of the materials (Omar et al., 2009). Also, the average difference in band gap values that determined from PL and reflectance measurements is around $1.05 \%$ and $1.01 \%$ for PSL formed on front $\mathrm{n}$ and back $\mathrm{p}$-side respectively.

\section{Chemical composition of PSL (FTIR):}

The FTIR spectra of the PS samples formed on front $\mathrm{n}$ and back $\mathrm{p}$ - side

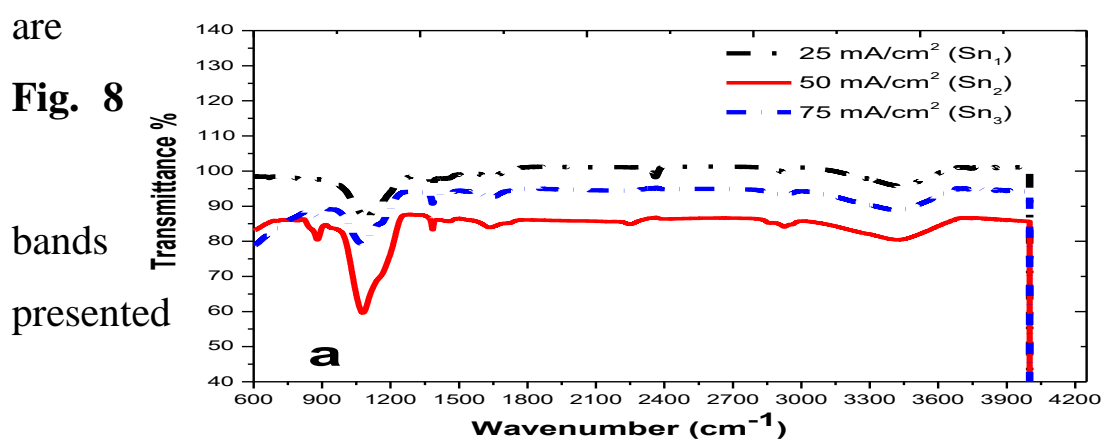

display in and several spectral are in Table 4.

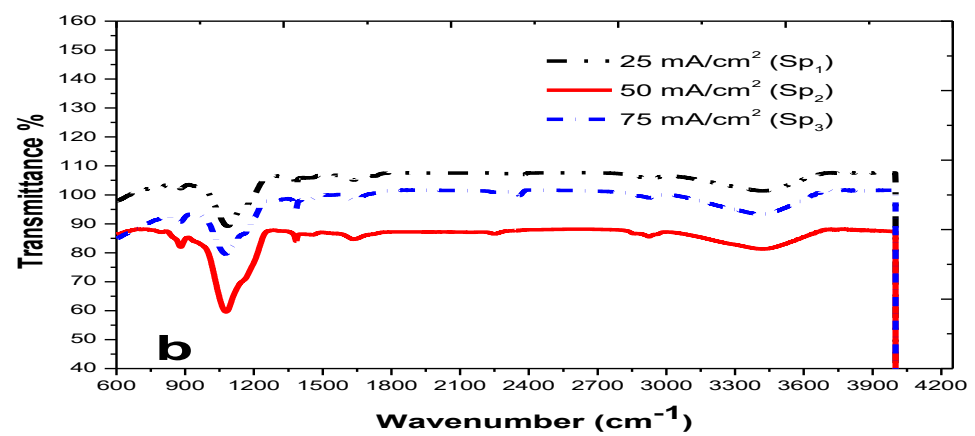


Figure 8. Transmittance of PSL samples prepared on (a): front $\mathrm{n}$-side $\left(\mathrm{Sn}_{1}, \mathrm{Sn}_{2}\right.$ and $\left.\mathrm{Sn}_{3}\right)$ and (b): back p-side $\left(\mathrm{Sp}_{1}, \mathrm{Sp}_{2}\right.$ and $\left.\mathrm{Sp}_{3}\right)$.

Table 4. wavenumber position corresponding to the different surface species associated with the PSL surface.

\begin{tabular}{|l|l|l|}
\hline $\begin{array}{c}\text { Surface } \\
\text { species }\end{array}$ & \multicolumn{1}{|c|}{$\begin{array}{c}\text { Peak } \\
\text { position } \\
\left(\mathbf{c m}^{-1}\right)\end{array}$} & \multicolumn{1}{c|}{ Modes } \\
\hline $\mathbf{O}-\mathbf{H}$ & 3420.35 & Strenching \\
\hline $\mathbf{C}-\mathbf{H}$ & 2924.75 & $\begin{array}{l}\text { C-H } \\
\text { strenching }\end{array}$ \\
\hline $\mathbf{C - O}$ & 1640.00 & Stretching vibration (bound group) \\
\hline $\mathbf{C}-\mathbf{H} 3$ & 1461.10 & Asymmetric stretching \\
\hline Si-O-Si & $1078-1091$ & Si-O-Si Asymmetric stretching \\
\hline Si-H & 880.0 & Si-O or Si-O-H bending \\
\hline Si-H & 630.0 & Si-H bending \\
\hline
\end{tabular}

Comparing both FTIR and PL data, the following consistencies are produced.

(i) The FTIR spectra of the samples with a relatively high PL intensity exhibit a developed broad transmission bands for the two sample $\mathrm{Sn}_{2}$ and $\mathrm{Sp}_{2}$.

(ii) A supplementary distinguishing feature of the FTIR spectra of the samples that display high PL intensities is the existence of 2 major bonds are resulted: one around $856-891 \mathrm{~cm}^{-1}$ and the second around $3420 \mathrm{~cm}^{-1}$. The last bonds are ascribed to $\mathrm{O}-\mathrm{H}$ stretching modes. The band between $856 \mathrm{~cm}^{-1}$ and $895 \mathrm{~cm}^{-1}$ is related to oxygen complexes, mostly $\mathrm{SiO}$ stretching in O-SiO and 
$\mathrm{C}-\mathrm{SiO}$, the formation of $\mathrm{Si}-\mathrm{O}-\mathrm{Si}$ bonds on the porous layers in the presence of humidity was detected by Maruyama and Ohtani (1994), Such presence of these bonds on the PSLs are responsible for the enhancement of PL intensity, and suggests that hydrogen passivation may not be the only parameter that responsible for the PL enhancement but depends on both hydrogen and oxygen passivation.

(iii) PL peak intensity and FTIR transmission peak intensity of PSL samples formed on front n-side are higher than those formed on the back p-side.

We can conclude that FTIR spectra of samples having higher bands concentrations attributed to hydrogen and oxygen complexes have more intense PL and lead to widen the band gap of the samples. So PSL is believed to be caused by a reduction in the Si dangling bond density. (Lenshin et al., 2011).

\section{Electrical properties of PSL:}

The solar cells are fabricated after PSL formation on the surface of both front n-side (group I samples) and back p-side (group $\Pi$ I samples) and both sides (group ПII samples) of $\mathrm{n}^{+} \mathrm{p} / \mathrm{Si}$ junction by ECE process

Few reports are reported on utilizing Au on PSL surface as front grid and Al for back surface contact by evaporation (Zimin et al., 1995; Bhattacharya et al., 2000; Rabinal and Mulimani, 2005). These electrical contacts are used in order to measure $\mathrm{J}-\mathrm{V}$ characteristics for the fabricated solar 
cells. Rabinal and Mulimani (2005) denoted that Al can act electron injector as well (minority carrier device) while Au can act as improved hole injector (majority carrier device) so that, using these contacts are thoughted to be remarkable for refining solar cell conversion energy, and are suggested to increase surface stability of the solar cell.

Figure 9 represents the $\mathrm{J}-\mathrm{V}$ characteristics of solar cells based on PSL formed on the front n-side (group I) and back p-side (group II) as well as cells without PSL have been measured at room temperature under dark and illumination of normal tungsten lamp with intensity of $100 \mathrm{~mW} / \mathrm{cm}^{2}$.
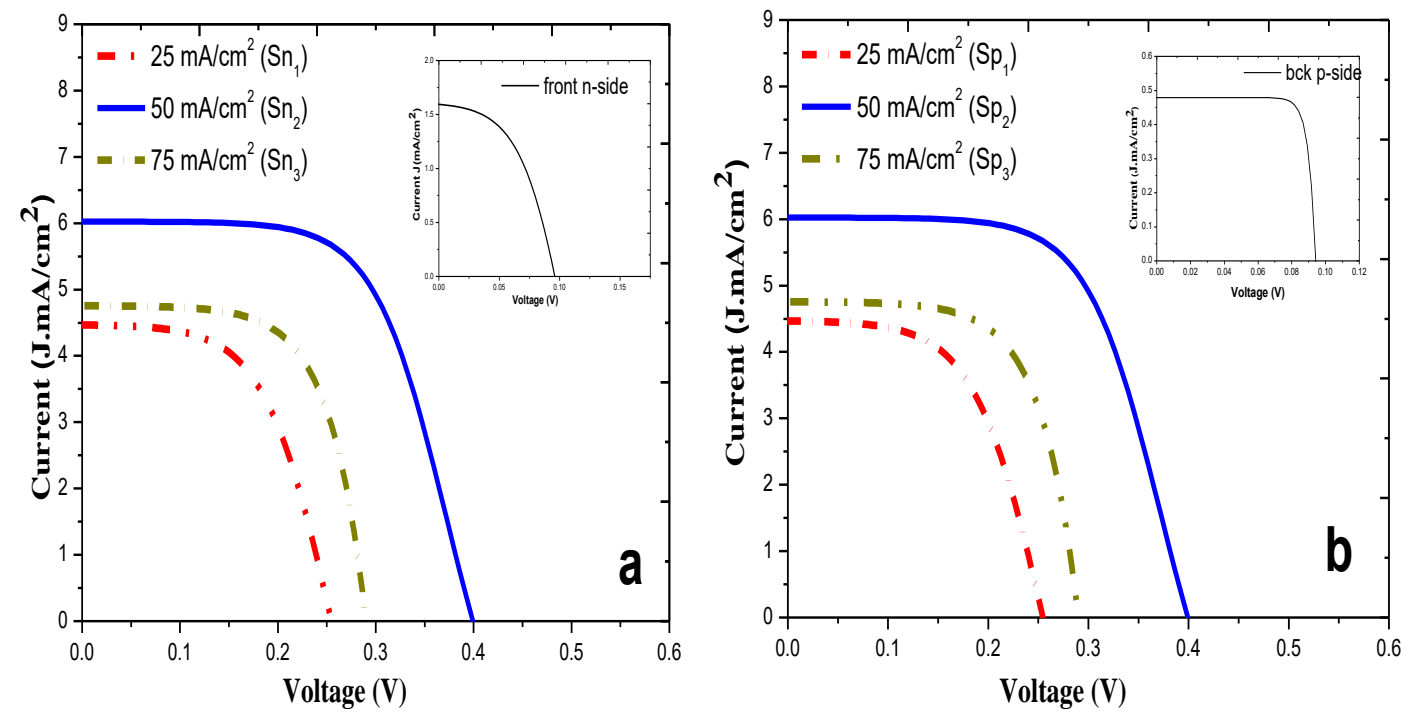
Figure 9. J-V characteristics of solar cell samples based on PSL prepared on (a): the front nside $\left(\mathrm{Sn}_{1}, \mathrm{Sn}_{2}\right.$, and $\left.\mathrm{Sn}_{3}\right)$ and (b): back p-side $\left(\mathrm{Sp}_{1}, \mathrm{Sp}_{2}\right.$ and $\left.\mathrm{Sp}_{3}\right)$ under illumination of ordinary tungsten lamp of $100 \mathrm{mw} / \mathrm{cm}^{2}$ compared with the solar cell without a PSL.

The open-circuit voltage $\left(\mathrm{V}_{\mathrm{oc}}\right)$, short-circuit current $\left(\mathrm{I}_{\mathrm{sc}}\right)$, maximum

\begin{tabular}{|c|c|c|c|c|c|c|}
\hline $\begin{array}{c}\text { Solar cell } \\
\text { Samples }\end{array}$ & $\begin{array}{c}\text { V max } \\
(\mathbf{V})\end{array}$ & $\begin{array}{c}\text { Jmax } \\
\mathbf{m A} / \mathbf{c m}^{2}\end{array}$ & $\begin{array}{c}\text { Voc } \\
(\mathbf{V})\end{array}$ & $\begin{array}{c}\text { Isc } \\
\left(\mathbf{m A} / \mathbf{c m}^{2}\right)\end{array}$ & $\begin{array}{c}\mathbf{F F} \\
\%\end{array}$ & $\begin{array}{c}\boldsymbol{\eta} \\
\%\end{array}$ \\
\hline
\end{tabular}

voltage $\left(\mathrm{V}_{\mathrm{m}}\right)$ and the maximum current $\left(\mathrm{I}_{\mathrm{m}}\right)$ are the prominent parameters that are determined from measured $\mathrm{J}-\mathrm{V}$ curve obtained, which used to investigate the efficiency $(\boldsymbol{\eta})$ of the solar cell (Youssef et al., 2015a).

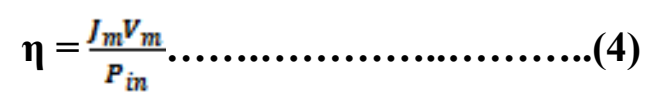

The degree of which $\mathrm{V}_{\mathrm{m}}$ matches with $\mathrm{V}_{\mathrm{oc}}$, as well as the degree to which $\mathrm{I}_{\mathrm{m}}$ matches with $\mathrm{I}_{\mathrm{sc}}$ can be described by the fill factor (FF) (Liu et al., 2014),

The fill factor (FF) was calculated by Eq. 5

$$
\mathrm{FF}=\frac{P_{m}}{I_{S C} V_{O C}}=\frac{J_{m} V_{m}}{I_{S C} V_{O C}} \ldots
$$




\begin{tabular}{|c|c|c|c|c|c|c|}
\hline \multicolumn{7}{|c|}{ GroupI } \\
\hline front n-side (no PSL) & 0.07 & 1.3 & 0.10 & 1.50 & 60.6 & 2.00 \\
\hline Sn1 & 0.24 & 3.0 & 0.28 & 3.25 & 79.00 & 2.25 \\
\hline Sn2 & 0.40 & 7.2 & 0.42 & 7.75 & 85.04 & 9.00 \\
\hline Sn3 & 0.30 & 4.5 & 0.35 & 4.80 & 80.35 & 4.20 \\
\hline \multicolumn{7}{|c|}{ GroupII } \\
\hline Back p-side (no PSL) & 0.08 & 0.40 & 0.10 & 0.70 & 45.70 & 1.00 \\
\hline Sp1 & 0.21 & 4.1 & 0.25 & 4.50 & 76.00 & 2.69 \\
\hline Sp2 & 0.35 & 5.7 & 0.4 & 6.00 & 81.10 & 6.23 \\
\hline Sp3 & 0.25 & 4.5 & 4.8 & 80.8 & 80.80 & 3.60 \\
\hline
\end{tabular}

Table (5): different solar cells parameters based on the PSL prepared on the n-side and back pside compared with the solar cell without a PSL.

The results above show that the two solar cells based on PSL formed on one side (front $\mathrm{n}$ and back p-side) at etching current of $50 \mathrm{~mA} / \mathrm{cm}^{2}$ give the best J-V characteristics. Thus, fabrication of solar cell based on both sides PSL at this condition would lead to increasing solar cell parameters, enhancing efficiency and reaching optimum condition for solar cell design that are best marketing in the industry. 
Figure 10 characterizes $\mathrm{J}-\mathrm{V}$ characteristics curves for solar cells samples based on both side PSL (group Ш) comparing to that based on one side PSL (group I and group II)
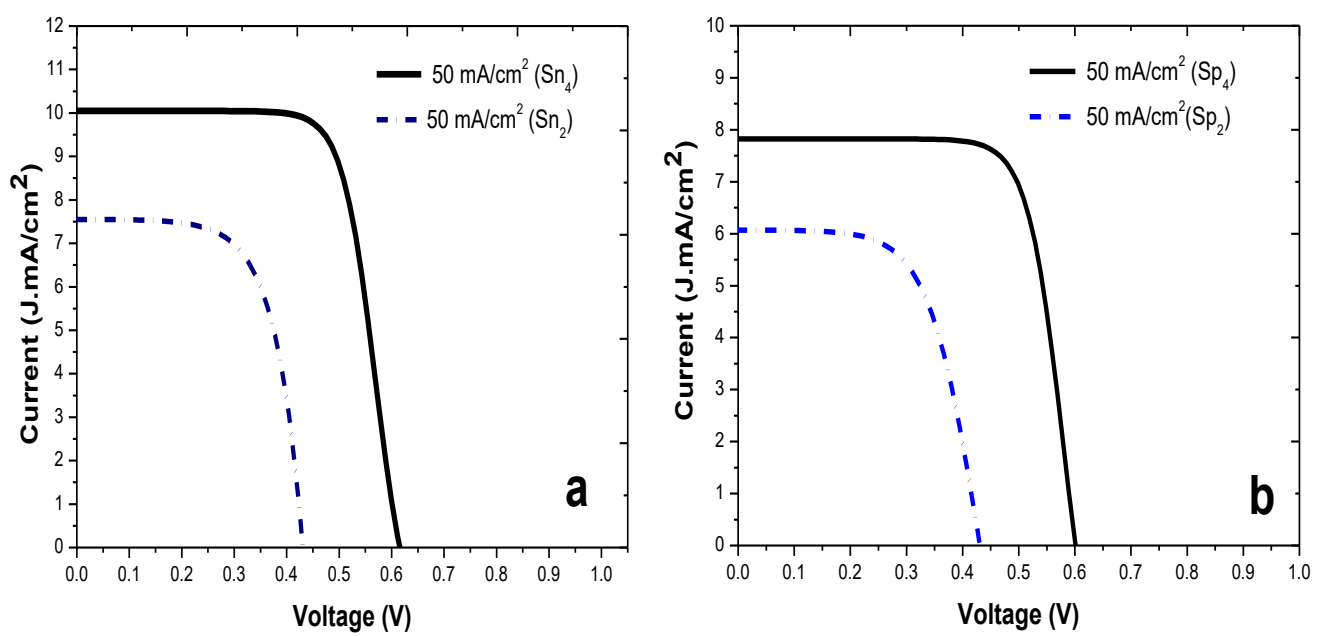

Figure 10. J-V characteristics of solar cell based on PSL prepared on (a): both sides $\left(\mathrm{Sn}_{4}\right.$ compared with that based one side $\left(\mathrm{Sn}_{2)}\right.$ and $(\mathrm{b})$ : both sides $\left(\mathrm{Sp}_{4}\right)$ compared with that based on one side $\left(\mathrm{Sp}_{2}\right)$.

Table 5. Different solar cells parameters based on the PSL prepared on both sides compared with that prepared on one side PSL at etching current density of $50 \mathrm{~mA} / \mathrm{cm}^{2}$.

\begin{tabular}{|c|c|c|c|c|c|c|c|}
\hline $\begin{array}{c}\text { Solar cell } \\
\text { Samples }\end{array}$ & $\begin{array}{l}\text { Group } \\
\text { No. }\end{array}$ & $\begin{array}{c}V_{\text {max }} \\
(\mathbf{V m})\end{array}$ & $\underset{\left(\mathbf{m A} / \mathbf{c m}^{2}\right)}{\operatorname{Jmax}}$ & $\begin{array}{l}\text { Voc } \\
\text { (V) }\end{array}$ & $\begin{array}{c}\text { Isc } \\
\left(\mathrm{mA} / \mathrm{cm}^{2}\right)\end{array}$ & FF\% & $\eta \%$ \\
\hline $\mathbf{S n}_{2}$ & group I & 0.40 & 7.2 & 0.42 & 7.75 & 85.04 & 9.0 \\
\hline $\mathrm{Sn}_{4}$ & group Ш & 0.55 & 10.0 & 0.62 & 10.2 & 87.00 & 17.0 \\
\hline Sp2 & group II & 0.35 & 5.7 & 0.40 & 6.0 & 81.10 & 6.23 \\
\hline $\mathrm{Sp}_{4}$ & group Ш & 0.52 & 7.5 & 0.60 & 8.0 & 82.15 & 12.0 \\
\hline
\end{tabular}


Table 5, shows that solar cell design based on both sides PSL provides stability and higher solar conversion efficiency solar cell conversion efficiency reach to $17.0 \%$ for sample $\mathrm{Sn}_{4}$ with respect to other samples and it is be recommended for industry marketing.

\section{CONCLUSION}

In this work, PSL are fabricated on front, back and both sides of $\mathrm{n}^{+}-\mathrm{p} / \mathrm{Si}$ junctions by electrochemical etching for different current densities of 25, 50 and $75 \mathrm{~mA} / \mathrm{cm}^{2}$ and 25 etching time. SEM shows that pore diameter, porosity and thickness increase at current density of $50 \mathrm{~mA} / \mathrm{cm}^{2}$ for front and back side. The recorded PL intensities (broadening and height) and hence obtained $\mathrm{Eg}_{\mathrm{s}}$ of PSL formed on front $\mathrm{n}$-side are higher than that formed on the back p-side. The FTIR spectra of PSL samples having higher bands concentrations attributed to hydrogen and oxygen complexes have more intense PL and lead to widen the band gap of the samples. A reduction in light reflection of PSL samples by increasing in current density to $50 \mathrm{~mA} / \mathrm{cm}^{2}$ compared to un treated textured $\mathrm{Si}$ surface. The electrical parameters for solar cells based on both side PSL provides maximum solar conversion efficiency compared to solar cells based on side. So, we suggest that solar cell based on both side PSL provides stability and higher solar conversion efficiency of $17 \%$ and it is being recommended for industry marketing.

\section{Acknowledgment}


We would like to thank Prof. Dr. Halah Kassem, The Head of Basic Science Department, Institute of Environmental Studies and Research for providing many facilities, helpful discussion and kind encouragement during this work.

\section{REFRENCES:}

Anglin, E.J., Cheng, L., Freeman, W.R., and Sailor, M.J: (2006): Porous silicon in drug delivery devices and materials. Advanced Drug Delivery Reviews, 60, 1266-1255.

Bhattacharya, E., Ramesh, P., and Kumar, C.S. (2000): Studies on gold/porous silicon/crystalline silicon junctions. Journal of Porous Materials, 7, 299301.

Bisi, O., Ossicini, S., \& Pavesi, L. (2000): Porous silicon: a quantum sponge structure for silicon-based optoelectronics. Surface science reports, 36(1), 1-126.

Dian, J., Macek, A., Nižňanský, D., Němec, I., Vrkoslav, V., Chvojka, T., \& Jelınek, I. (2004): SEM and HRTEM study of porous silicon relationship between fabrication, morphology and optical properties. Applied Surface Science, 236(1), 169-154.

Dzhafarov, T. (2013): Solar Cells-research and Application, Perspectives, in: A. Morales Acevedo (Ed.), Intech Open, USA. 
Dubey, R. S., and Gautam, D. K. (2009): Fabrication and characterization of porous silicon layers for applications in optoelectronics. Optical and Quantum Electronics, 41(3), 169-201.

Fang, X., Rong, J., \& Zhou, C. (2013): Review of porous silicon preparation and its application for lithium-ion battery anodes. Nanotechnology, 24(42), 422001.

Kulathuraan, K., Mohanraj, K., \& Natarajan, B. (2016): Structural, optical and electrical characterization of nanostructured porous silicon: Effect of current density. Spectrochimica Acta Part A: Molecular and Biomolecular Spectroscopy, 152, 51-55.

Kubelka, P., \& Munk, F. (1931): An article on optics of paint layers. Technical Physics, 12, 593-601.

Kubelka, P. (1946): New contributions to the optics of intensely lightscattering materials. Part I. Josa, 36(5), 446-455.

Len'shin, A. S., Kashkarov, V. M., Turishchev, S. Y., Smirnov, M. S., \& Domashevskaya, E. P. (2011). Effect of natural aging on photoluminescence of porous silicon. Technical Physics Letters, 35(9), 569-592.

Liu, D., \& Kelly, T. L. (2014): Perovskite solar cells with a planar heterojunction structure prepared using room-temperature solution processing techniques. Nature photonics, 6(2), 133-136.

Maruyama, T., Ohtani, S. (1994): Photoluminescence of porous silicon 
exposed to ambient air. Journal of Applied Physics Letter, 65, 1346.

Omar, K., Hassan, Z., Ramzy, A., \& Abu Hassan, H. (2009): Laser effects on porous silicon synthesis by photoelectrochemical etching process. Journal of optoelectronics and advanced materials, 11(11), 1641-1646.

Otsuka, M. (2004): Comparative particle size determination of phenacetin bulk powder by using Kubelka-Munk theory and principal component regression analysis based on near-infrared spectroscopy. Powder Technology, 141(3), 244-250.

Ou, W. Y., Zhang, Y., Li, H. L., Zhao, L., Zhou, C. L., Diao, H. W., \& Wang, W. J. (2011). Effects of IPA on texturing process for mono-crystalline silicon solar cell in TMAH solution. In Materials Science Forum, 665, 3135 .

Rabinal, M.K. and Mulimani, B.G. (2005): Transport properties of molecularly stabilized porous silicon Schottky junctions. New Journal of Physics, 9, $440-446$.

Rajabi, M., \& Dariani, R. S. (2009): Current improvement of porous silicon photovoltaic devices by using double layer porous silicon structure: applicable in porous silicon solar cells. Journal of Porous Materials, 16(5), 513-519.

Ramizy, A., Hassan, Z., Omar, K., Al-Douri, Y., \& Mahdi, M. A. (2011): New optical features to enhance solar cell performance based on porous silicon surfaces. Applied Surface Science, 255(14), 6112-6115. 
Salcedo, W. J., Ramirez Fernandez, F. J., \& Galeazzo, E. (1995): Structural characterization of photoluminescent porous silicon with FTIR spectroscopy. Brazilian Journal of Physics, 25, 156-161.

Sailor, M.J. (2014): Fundamentals of Porous Silicon Preparation, Porous Silicon in Practice: Preparation, Characterization and Applications, WileyVCH Verlag GmbH \& Co. KGaA, Germany, 1-42.

Salman, K. A., Hassan, Z., \& Omar, K. (2012): Effect of silicon porosity on solar cell efficiency. Intarnational Journal of Electrochemistry Scientific, 5(1), 356-366.

Salonen, J., Lehto, V. P., \& Laine, E. (1995): The room temperature oxidation of porous silicon. Applied surface science, 120(3), 191-196.

Schneider B. W., Lal N. N., Baker-Finch S., White T. P. (2014): Pyramidal surface textures for light trapping and antireflection in perovskite-onsilicon tandem solar cells. Optics Express, 22(21), 1422-1430.

Singh P. K., Kumar R., Lal M., Singh S. N., Das B. K. (2001): Effectiveness of anisotropic etching of silicon in aqueous alkaline solutions. Solar Energy Materials and Solar Cells, 50(1):83-113.

Sun, K., Shen, S., Liang, Y., Burrows, P. E., Mao, S. S., \& Wang, D. (2014): Enabling silicon for solar-fuel production. Chemical reviews, 114(15), 6662-6519. 
Tauc, J., Grigorovici, R., \& Vancu, A. (1966): Optical properties and electronic structure of amorphous germanium. physica status solidi (b), 15(2), 625635.

Uhlir, A. (1956): Electrolytic shaping of germanium and silicon. Bell Labs Technical Journal, 35(2), 333-345.

Yerokhov, V., Melnyk, I., Tsisaruk, A., \& Semochko, I. (2000): Porous silicon in solar cell structures. Optoelectronics Review, (4), 414-415.

Youssef, G. M., El-Nahass, M. M., El-Zaiat, S. Y., \& Farag, M. A. (2015a): Effect of porosity on the electrical and photoelectrical properties of textured $\mathrm{n}+\mathrm{p}$ silicon solar cells. Materials Science in Semiconductor Processing, 39, 455-466.

Youssef, G. M., El-Zaiat, S. Y., El-Malky, M., \& Nawar, H. A. (2015b): preparation and physical characterization of porous silicon layers for sensing applications. International Journal of Physics and Research (IJPR), 5(3), 33-46.

Youssef, G. M. (2016): the effect of etching current on the formation of antireflection porous silicon coating fabricated by electrochemical technique for solar cells. International Journal of Physics and Research (IJPR), 6(1), 5-20.

Zimin, S.P., Kuznetsov, V.S., and Prokaznikov, A.V. (1995): Electrical characteristics of aluminum contacts to porous silicon. Applied Surface Scientific, 91, 355-356. 


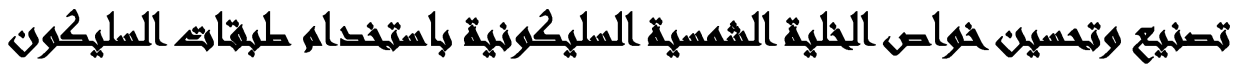

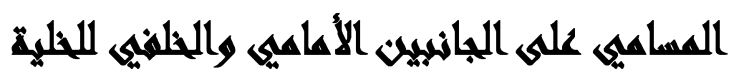

هاجر عبد الحكيم نوار " ، جمال محمود يوسف1، محمود محمد النحاس"، محمد غريب المالكي"،

\author{
1) كلية العلوم - قسم الفيزياء - جامعة عين شمس

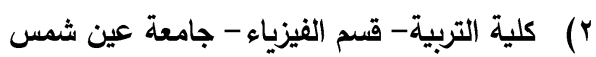

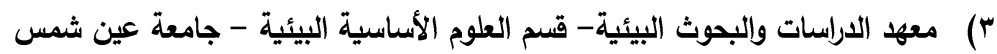

\begin{abstract}
المستخله
يعتبر السليكون المسامي ذو تطبيقات هامة في مجال الخلايا الثمسية وذلك بسب مساحة السطح

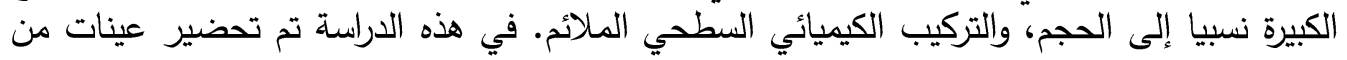

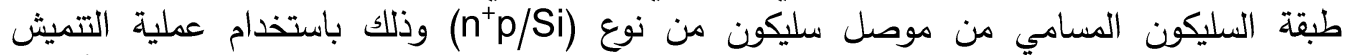

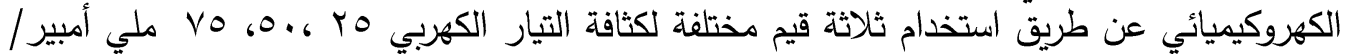

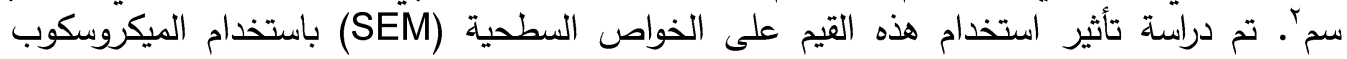

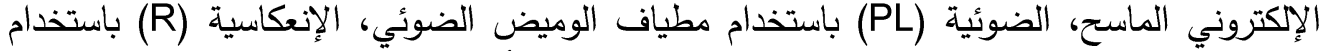

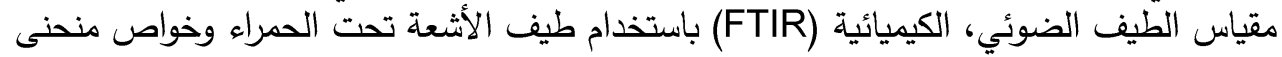

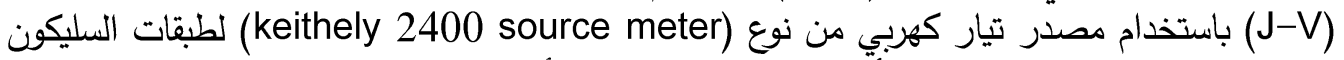

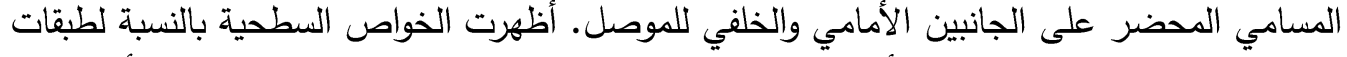

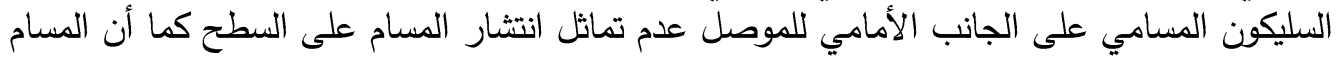

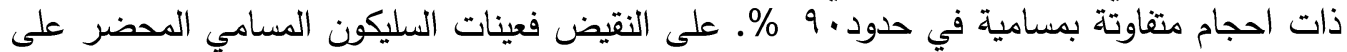

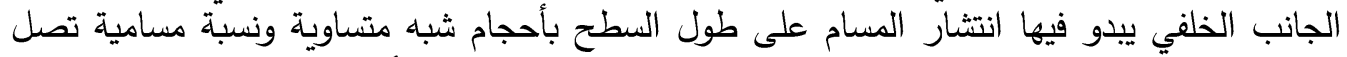

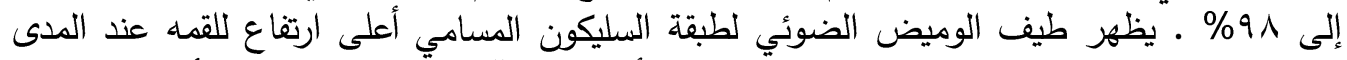

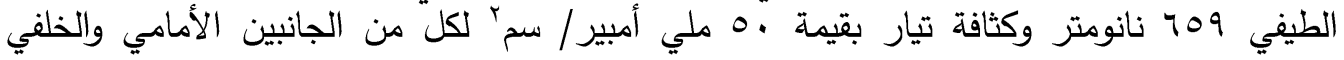

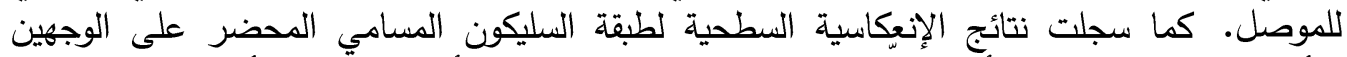

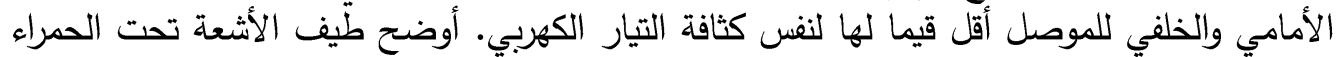

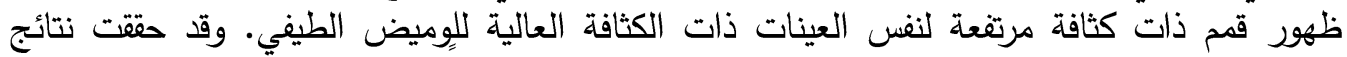
استخدام طبقة السليكون المسامي على الجانبين الأمامي والخلفي معا للخلية الثمسية إلى زيادة كفاءتها
\end{abstract}


بنسبة تصل إلى V I ل لذلك فإن استخدام طبقات السليكون المسامي على الجانبين الأمامي والخلفي للخلية الثمسية يزيد من فاعليتها ويوصي به لإستخدامة كأحد التواد الهامة في صناعة الخايلايا 